\title{
Surface slicks associated with tidally forced internal waves may transport pelagic larvae of benthic invertebrates and fishes shoreward
}

\author{
A. L. Shanks \\ Marine Biology Research Division, Scripps Institution of Oceanography, La Jolla, California 92093, USA
}

\begin{abstract}
For 3 mo, pelagic larvae of the intertidal crab Pachygrapsus crassipes were collected daily at a single site located several hundred meters from the shore. The daily abundance of the larvae fluctuated with fortnightly maxima that preceded the maxima in the daily tidal range by about $5 \mathrm{~d}$. These data suggest that the larvae might be carried ashore in surface slicks generated by tidally forced internal waves. Such slicks transported drogues 1 to $2 \mathrm{~km}$ shoreward in 2 to $3 \mathrm{~h}$ on 2 out of 5 dates; on the dates when transport occurred pelagic larvae of a variety of invertebrates and fishes were 6 to 40 times more concentrated near the surface in the slicks than near the surface of the water between the slicks. The reason why the slicks failed to transport drogues shoreward on 3 dates is not known; however, on these dates, the abundance of larvae near the surface was not significantly greater in the surface slicks than in the zones between the slicks. These observations suggest that concentration and transport in slicks associated with tidally driven internal waves may be an important means for the onshore transport of pelagic life history stages of marine organisms.
\end{abstract}

For many marine invertebrates and fishes, the temporal and spatial distribution of pelagic developmental stages influences the subsequent population structure of later stages in the life history. For example, timing, location and intensity of recruitment for juveniles of intertidal invertebrates (Underwood, 1979) and coral fishes (Doherty, 1983) are influenced by the heterogeneous distribution of their pelagic larvae. Such heterogeneity may result not only from adult distributions and breeding periodicities, but also from some combination of the pelagic stages' survivorship, behavior and transport by physical oceanographic processes.

In spite of the obvious importance of quantitative field studies of the pelagic developmental stages of marine organisms, technical difficulties have hampered work on the subject. In the present study I measured: temporal fluctuations in abundance of pelagic larvae of a crab at a given location and simultaneous spatial fluctuations in the abundance of pelagic larvae of several kinds of invertebrates and fishes. For species and location studied, there was a strong correlation between larval abundance and physical oceanographic phenomena.

From early August through early November 1982, pelagic megalopa larvae of the crab Pachygrapsus crassipes were collected daily at the seaward end of the pier at the Scripps Institution of Oceanography. The pier is $320 \mathrm{~m}$ long and projects perpendicularly from a coastline that runs north-south; water depth at the end of the pier is about $6 \mathrm{~m}$, and the bottom is sandy. The crab larvae were captured in traps that consisted of bundles of hemp rope or surf grass. Each bundle was about $1 \mathrm{~m}$ long and was bound tightly around the center (the diameter at the binding was about $3 \mathrm{~cm}$ ). These traps were at 2 depths (just beneath the sea surface and at $1.5 \mathrm{~m}$ ) beneath a bank of fluorescent lamps. From mid October through mid November 1982 , other traps were also set about $30 \mathrm{~m}$ from the seaward end of the pier, where there were no nearby lights; traps at this dark location were at 3 depths (just beneath the surface, $1.5 \mathrm{~m}$ and $6 \mathrm{~m}$ ). Each day megalopa larvae of $P$, crassipes, the most abundant of the larval organisms present, were quantitatively recovered from the traps at about midday. The trap bundle was vigorously shaken for about $1 \mathrm{~min}$ in a bucket of seawater to remove the crab larvae. A single washing recovers about $90 \%$ of the megalopa. On the average, traps under the lights caught 16 times more megalopa larvae of $P$. crassipes $\mathrm{d}^{-1}$ (S. D. $=14$ times, $\mathrm{n}=30 \mathrm{~d}$ ) than traps on the dark side of the pier. In the lab the megalopae display strong positive phototactic behavior and at night the pier lights probably attract the larvae to the illuminated traps. In the traps under 


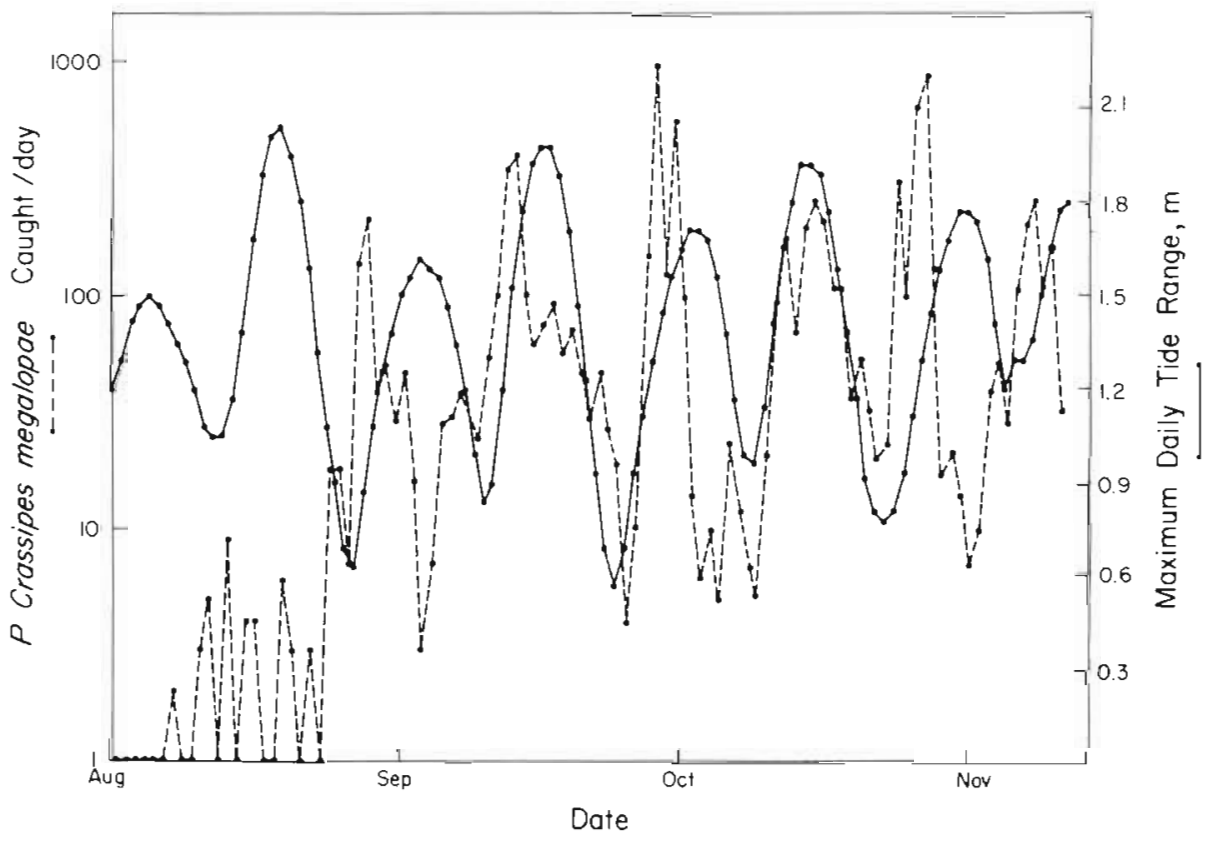

Fig. 1. Pachygrapsus crassipes. Log of daily catch of megalopa larvae from traps $10 \mathrm{~m}$ plus $1.5 \mathrm{~m}$ ) hung under the ligths at the end of Scripps pier (dashed line) plotted against maximum tidal range per $24 \mathrm{~h}$ period (solid line) the lights, the catch at the surface and at $1.5 \mathrm{~m}$ ranged from 0 to 957 larvae $\mathrm{d}^{-1}$ and 0 to 50 larvae $\mathrm{d}^{-1}$, respectively, with large fluctuations from day to day (Fig. 1). Of the larvae caught under the lights, on the average $94 \%$ (S. D. $=7 \%, \mathrm{n}=90$ d) were caught in the surface trap. A similar distribution of mean daily catch was found on the unilluminated traps: $91 \%$ (S. D. $=11 \%, \mathrm{n}=30 \mathrm{~d}$ ) at $0 \mathrm{~m} 6 \%$ (S. D. $=7 \%, \mathrm{n}=$ $30 \mathrm{~d}$ ) at $1.5 \mathrm{~m}$, and $3 \%(\mathrm{~S} . \mathrm{D} .=6 \%, \mathrm{n}=30 \mathrm{~d}$ ) just above the bottom $(6 \mathrm{~m})$. Apparently, most of the megalopae are very near the sea surface when they arrive at the traps, whether the trap is under a light or not.

Between 1 and 24 August megalopa larvae of Pachygrapsus crassipes occurred sporadically in the catch with a total of only 37 caught during this period. Following 24 August there was an abrupt increase in the number caught such that by 29 August the catch had risen to 210 individuals $\mathrm{d}^{-1}$. This dramatic increase in catch is perhaps due to synchronous larval release by the adults some months previously.

Greatest daily abundance of megalopa larvae occurred on 14, 28 August, 13, 28 September, 16, 28 October and 9 November (Fig. 1). These maxima recurred on the average every $14.5 \mathrm{~d}(\mathrm{~S} . \mathrm{D} .=2.4 \mathrm{~d}, \mathrm{n}=6$ cycles), which is not significantly different from a fortnightly cycle $\left(\mathrm{x}^{2}=2.08, \mathrm{P}>0.10\right)$. The record from the traps on the dark side of the pier, though shorter, is quite similar to this (linear correlation of catch in the illuminated traps vs the unilluminated traps, $\mathrm{r}=0.677$, $\mathrm{n}=30 \mathrm{~d}, \mathrm{P}<0.01)$. Between 25 August and 12 November 1982, no significant linear correlation or cross correlations were found between the daily catch, and the strength of the onshore component of the winds measured at the Scripps pier. The apparent fortnightly period of the peak catches suggested that recruitment might correlate with the tides. In Fig. 1 the $\log$ of the daily catch of megalopae on the 2 lighted traps (surface plus $1.5 \mathrm{~m}$ ) is plotted together with the maximum daily tidal range. Significant cross correlations (Otnes and Enochson, 1978) between tide range and log of the daily catch of megalopae occurred around a lag of $+5 \mathrm{~d}$ (Fig. 2), which indicates that the peak catches regularly occurred about $5 \mathrm{~d}$ before the spring tide. These data suggest that the megalopae are not transported shoreward by wind driven currents, but may be carried to shore from the offshore plankton at the surface on tidal currents. On the Southern Califor-

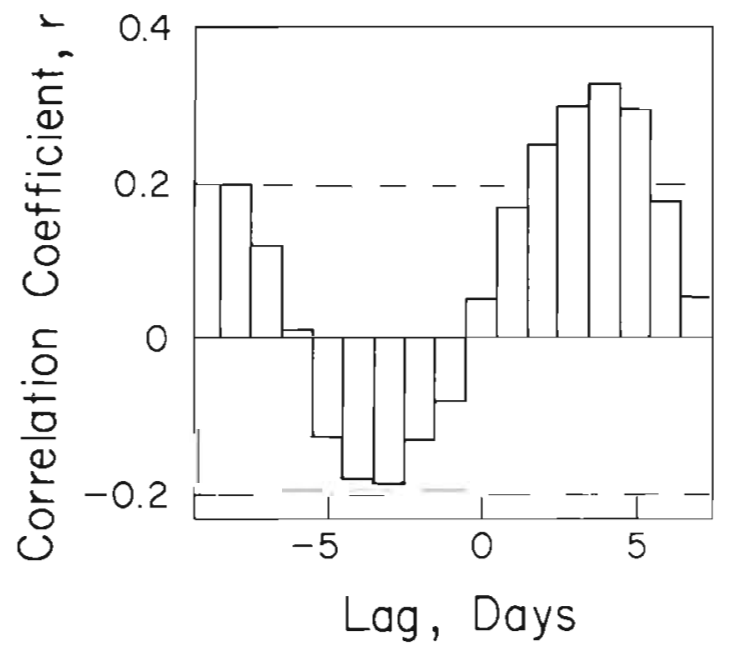

Fig. 2. Pachygrapsus crassipes. Cross correlation of daily catch of megalopa larvae vs. maximum daily tidal range. Cross correlation was limited to lags of $\pm 8 \mathrm{~d}, 10 \%$ of record length (Otnes and Enochson, 1978). Critical $r=0.217$ for $\mathrm{P}<0.05$ and $\mathrm{n}=80$ 
nia continental shelf, on-off shore baroclinic currents are generated by the tides (Winant and Olson, 1976).

The baroclinic currents are caused as internal tidal waves progress shoreward across the shelf (Winant and Olson, 1976; Winant, 1980). The internal waves are formed as the tides pass over the shelf break (Rattray, 1960). On the Southern California continental shelf the internal waves have a fortnightly cycle correlated with the tide range (Cairns, 1967, 1968). The largest waves, generated during spring tides, break and progress across the shelf as bores, producing near-bottom onshore flow and surface off shore flow (Winant and Bratkovish, 1981; Winant and Olson, 1976). During tides with smaller range, trains of internal waves of lesser magnitude are formed which proceed across the shelf unbroken (Cairns, 1968; Winant, 1980). If megalopae were using broken internal waves as a means of shoreward transport, one would expect maximum catches near the botton where the shoreward flow occurs, and around the spring tide when the flow is strongest. But, the maximum catch consistently occurred at the surface, and about $5 \mathrm{~d}$ before spring tide, with a sharp drop in the size of the catch at spring tide. This suggests that these megalopae were not carried onshore on bores caused by broken internal waves, but are somehow transported by the unbroken internal waves.

At low wind speeds, internal waves have a visible surface manifestation in the form of wide slicks, oriented parallel to the bottom topography, which progress shoreward with the internal waves (Ewing, 1950; LaFond, 1959a). Currents generated over the wave cause a convergence over the trough of the wave and a divergence over the crest (Ewing, 1950). At the convergence, oils and flotsam often accumulate, materials which because of their bouyancy cannot follow the downward water movement (Arthur, 1954). These patches of flotsam have on occasion been observed to progress shoreward with the slicks (Arthur, 1954; LaFond, 1959b; own obs.). If slicks can accumulate and transport flotsam shoreward then they might also transport larvae which reside at the sea surface shoreward. If megalopae are being transported ashore in slicks then, like flotsam, they should be highly concentrated in the slicks.

To test whether a slick is trapping flotsam and transporting it shoreward, styrofoam cups, weighted with sand so they floated with their rims just at the surface, were employed as surface drogues. The drogues were deployed in long lines perpendicular to visible bands of slicks. Each line was about $1 \mathrm{~km}$ long, consisting of 50 cups spaced $20 \mathrm{~m}$ apart. The seaward end of the line was between about 3 and $5 \mathrm{~km}$ from shore. The drogues were left in place for 2 to $3 \mathrm{~h}$. In order to examine whether the concentration of larvae is higher in the slicks than in the rippled water between slicks, replicate $5 \mathrm{~min}$ neuston net tows (net opening $1.0 \times 0.3 \mathrm{~m}$, mesh size $0.505 \mathrm{~mm}$ ) were made along the slicks as well as in the ripples between slicks across which the line of drifters had been set. Observations were made on 6, 12, and 19 August 1982, 14 September 1982 , and 2 October 1982 directly offshore from Scripps pier.

On 3 of the 5 sampling dates (6 August, 14 September, and 2 October) the drogues were not transported by the slicks. At the end of the experiment the cups were still more or less in a line, they were present in both slicks and ripples, and they had not moved appreciably shoreward. On these dates there were no significant differences $(\mathrm{P}>0.10)$ between the concentrations of larval invertebrates, larval fishes, and other planktonic animals in the slicks and in the rippled water between the slicks.

On 2 dates, 12 and 19 August 1982, the results were dramatically different. As each cup in the line was overtaken by a slick it was caught and carried shoreward in the slick for the duration of the experiment. At the end of the experiment the cups were no longer in a line, over $90 \%$ were clumped in 1 or 2 slicks, and they had been transported 1 to $2 \mathrm{~km}$ shoreward from the seaward end of the line of release. Associated with the slicks were dense accumulations of flotsam. On these dates there were also marked concentrations of larvae of invertebrates and fishes in the slicks (Table 1). The megalopae of several species of crabs, including Pachygrapsus crassipes, larvae of shrimp, fish, and polychaetes, and brachyuran and anomuran zoea were all about an order of magnitude more numerous in slicks than in rippled water between the slicks. Small (1 to $2 \mathrm{~mm}$ ) flatworms were extremely numerous in slicks, with average concentrations more than 200 fold the values observed in the ripples. In the rippled water between slicks small doliolids and cnidaria were significantly more numerous than in the slicks. These normally midwater plankters had probably been swept to the surface by the diverging currents over the peak of the wave. These data indicate that larval forms in the surface layer can at times be highly concentrated in slicks and if they can maintain their position in the surface layer then they may, like flotsam, be transported shoreward.

It is not clear why some slicks concentrate and transport material shoreward while others do not. Such differences are not, in principle, surprising since the strength of the currents over internal waves is dependent on many factors, including the depth of the thermocline, the wave amplitude, and wave length (LaFond, 1959b). In general, waves with crests near the surface generate greater surface currents than waves with their crests deeper in the water column. Presum- 
Table 1. Number (Mean \pm S. D.) of animals caught in 5 min net tows near the surface through slicks and rippled water between slicks on 12 and 19 August 1982, days when the slicks caught the surface drifters

\begin{tabular}{|c|c|c|c|c|c|c|}
\hline Animal & $\begin{array}{c}\text { Ripples } \\
\mathrm{n}=4\end{array}$ & $\begin{array}{l}12 \text { August } \\
\text { Slicks } \\
\mathrm{n}=4\end{array}$ & $\begin{array}{l}\text { Conc. } \\
\text { factor }^{d}\end{array}$ & $\begin{array}{l}\text { Ripples } \\
\mathrm{n}=3\end{array}$ & $\begin{array}{l}19 \text { August } \\
\text { Slicks } \\
n=3\end{array}$ & $\begin{array}{l}\text { Conc. } \\
\text { factor }^{d}\end{array}$ \\
\hline $\begin{array}{l}\text { Brachyura } \\
\text { (megalopae) }\end{array}$ & $1.0 \pm 0.8$ & $11.5 \pm 7.3$ & $12^{\mathrm{a}}$ & $7.0 \pm 5.3$ & $280.3 \pm 29.7$ & $40^{\mathrm{a}}$ \\
\hline $\begin{array}{l}\text { Brachyura } \\
\text { (zoea) }\end{array}$ & $1.8 \pm 2.9$ & $4.3 \pm 13.5$ & $2^{c}$ & $13.3 \pm 7.6$ & $79.7 \pm 21.4$ & $6^{b}$ \\
\hline $\begin{array}{l}\text { Porcellana } \\
\text { (zoea) }\end{array}$ & $0.8 \pm 1.5$ & $25.8 \pm 30.4$ & $32^{a}$ & $342.3 \pm 161.7$ & $3273.3 \pm 1843.5$ & $10^{\mathrm{a}}$ \\
\hline $\begin{array}{l}\text { Shrimp } \\
\text { (larval) }\end{array}$ & $19.0 \pm 29.5$ & $365.3 \pm 419.5$ & $19^{a}$ & $10.7 \pm 5.0$ & $173.3 \pm 71.8$ & $16^{\mathrm{a}}$ \\
\hline $\begin{array}{l}\text { Fish } \\
\text { (larval) }\end{array}$ & $2.3 \pm 1.7$ & $28.8 \pm 20.8$ & $13^{\mathrm{a}}$ & $3.7 \pm 3.8$ & $134.0 \pm 52.4$ & $36^{2}$ \\
\hline $\begin{array}{l}\text { Annelids } \\
\text { (larval) }\end{array}$ & $4.0 \pm 2.9$ & $13.5 \pm 13.5$ & $3^{c}$ & $0.3 \pm 0.6$ & $23.0 \pm 21.4$ & $77^{a}$ \\
\hline Flatworms & $118.3 \pm 223.9$ & $25000 \pm 31000$ & $211^{\mathrm{a}}$ & $21.7 \pm 27.1$ & $5772.0 \pm 4773.8$ & $266^{a}$ \\
\hline Copepods & $6233.8 \pm 3280.9$ & $3138.3 \pm 5286.8$ & $0.5^{c}$ & $1694.3 \pm 1350.0$ & $2223.0 \pm 413.4$ & $1.3^{c}$ \\
\hline Doliolids & $4.5 \pm 1.3$ & $0.8 \pm 1.5$ & $0.2^{\mathrm{a}}$ & $364.0 \pm 519.3$ & $4.3 \pm 7.5$ & $0.1^{\mathrm{c}}$ \\
\hline Cnidaria & $47.8 \pm 29.0$ & $2.8 \pm 2.4$ & $0.1^{\mathrm{a}}$ & $290.3 \pm 231.2$ & $47.7 \pm 39.7$ & $0.2^{c}$ \\
\hline
\end{tabular}

ably it is these shallow waves, which generate currents strong enough to concentrate flotsam in the convergence and keep it there, that transport material shoreward.

Banded slicks associated with internal waves have been observed along many coasts, both island and continental (Apel et al., 1975; Fu and Holt, 1982). The factors necessary for these internal waves and the associated slicks - shelf, thermocline and tides (Rattray, 1960) - are common coastal features. The behavioral mechanisms assisting an organism in exploiting the transporting capacity of slicks are those which maintain an organism in the neuston, i.e. positive phototaxis, negative geotaxis, positive barokinesis and/or thigmotaxis. These mechanisms are displayed by a variety of larvae (Mackay, 1943; Thorson, 1964; Rice, 1966; Sulkin, 1973; Ennis, 1975; Sulkin and Van Heukelem, in press), including the megalopae of Pachygrapsus crassipes (own obs.) and the post larvae of a galatheid crab which have been observed to be densely concentrated in banded slicks off New Zealand (Zeldis and Jillett, 1982). The prevalence of slicks around the world, the simple behavioral patterns necessary to exploit them, and the increased concentrations of larval decapods in them suggest that slicks may be a common route of onshore larval transport.

\section{LITERATURE CITED}

Apel, J. R., Byrne, H. M., Proni, J. R., Chamell, R. L. (1975) Observations of oceanic internal and surface waves from the earth resources technology satellite. J. geophys. Res. 80: $865-881$

Arthur, R. S. (1954). Oscillilations in sea temperature at Scripps and Oceanside piers. Deep Sea Res. 2: 129-143

Cairns, J. L. (1967). Asymmetry of internal tidal waves in shallow coastal waters. J. geophys. Res. 72: 3563-3565

Cairns, J. L. (1968). Thermocline strength fluctuations in coastal waters. J. geophys. Res. 73: 2591-2595

Doherty, P. J. (1983). Tropical territorial Damselfishes: is density limited by aggression or recruitment? Ecology 64: $176-190$

Ennis, G. P. (1975). Behavioral responses to changes in hydrostatic pressure and light during larval development of the lobster Homarus americanus. J. Fish. Res. Bd Can. 32: 271-281

Ewing, G. (1950). Slicks, surface films and internal waves. J. mar. Res. 9: 161-187

Fu, L.-L., Holt, B. (1982). Seasat views oceans and sea ice with synthetic-aperture radar. Jet Propulsion Laboratory Publication $81-120$, p. 26-42

LaFond, E. C. (1959a). Sea surface features and internal waves in the sea. Indian J. Meterol. Geophys. 10: 415-419

LaFond, E. C. (1959b). Slicks and temperature structure in the sea. Navel Electronics Lab Report 937: 1-27

MacKay, D. C. G. (1943). The behavior of the Pacific edible crab Cancer magister. J. Comp. physiol. Psychol. 36: 255-268

Otnes, R. K., Enochson, L. (1978). Applied time series analysis, Vol. 1, Basic techniques. Wiley, New York

Rattray, M. Jr (1960). On the coastal generation of internal tides. Tellus 12: 54-62

Rice, A. L. (1966). The orientation of pressure response of some marine crustaceans. In: Proceedings of the Symposium on Crustacea, Part III, Marine Biological Association Indla, p. 1124-1131

Sulkin, S. D. (1973). Depth regulation of crab larvae in the absence of light. J. exp. mar. Biol. Ecol. 13: 73-82 
Sulkin, S. D., Van Heukelem, W. (in press). Larval recruitment in the crab Callinectes sapidus Rathburn: an amendment to the larval retention in estuaries. In: Kennedy $V$. (ed.) Estuarine comparisons. Academic Press, New York

Thorson, B. (1964). Light as an ecological factor in the dispersal and settlement of larval marine bottom invertebrates. Ophelia 1: 167-208

Underwood, A. J. (1979). The ecology of intertidal gastropods. Adv. mar. Biol. 16: 111-210

Winant, C. D. (1980). Downwelling over the Southern California shelf. J. phys. Oceanog. 10: 791-799
Winant, C. D., Bratkovish, A. W. (1981). Temperature and currents on the Southern California shelf: a description of the variability. J. phys. Oceanog. 11: 71-86

Winant, C. D., Olson, J. R. (1976). The vertical structure of coastal currents. Deep Sea Res. 23: 925-936

Zeldis, J. R., Jillett, J. B. (1982). Aggregation of pelagic Munida gregaria (Fabricius) (Decapoda, Anomura) by coastal fronts and internal waves. J. Plankton Res. 4: 839-857

Accepted for printing on June 13, 1983 